\title{
Short communication: Differential immunoglobulin transfer during mastitis challenge by pathogen-specific components
}

\author{
O. Wellnitz, ${ }^{1}$ E. T. Arnold, M. Lehmann, and R. M. Bruckmaier \\ Veterinary Physiology, Vetsuisse Faculty, University of Bern, CH-1725 Posieux, Switzerland
}

\section{ABSTRACT}

Mastitis induced by Escherichia coli is often characterized by severe clinical signs, indicating a more powerful combat of the immune system against the pathogen compared with Staphylococcus aureus infections, which are often represented by chronic and subclinical diseases. The aim of this study was to test the major pathogenic component lipopolysaccharide (LPS) from E. coli and lipoteichoic acid (LTA) from Staph. aureus for their effects on blood-milk barrier integrity and the related transfer of immunoglobulins and lactate from blood into milk. A similar somatic cell count (SCC) increase was achieved by intramammary challenge of 1 quarter of 5 cows with $20 \mu \mathrm{g}$ of LTA, and 8 cows with $0.2 \mu \mathrm{g}$ of LPS (maximum $\log \mathrm{SCC} / \mathrm{mL}$ : 7). Milk $\operatorname{IgG}_{1}$ concentrations increased in LPS- but not in LTA-challenged quarters. Milk $\operatorname{IgG}_{2}$ concentrations were increased in treated quarters at $3 \mathrm{~h}$ after LPS, and $6 \mathrm{~h}$ after LTA challenge. Higher maximum levels of $\mathrm{IgG}_{2}$ were reached in milk of LPS-treated quarters (173 $\pm 58 \mu \mathrm{g} / \mathrm{mL}$ ) than of LTA-challenged quarters (62 \pm $13 \mu \mathrm{g} / \mathrm{mL}$ ). Immunoglobulin $\mathrm{G}_{1}$ and $\operatorname{IgG}_{2}$ levels did not change in control quarters. L-Lactate concentrations in milk increased $4 \mathrm{~h}$ after LPS and $5 \mathrm{~h}$ after LTA challenge and reached higher maximum levels in LPS- (221 $\pm 48 \mathrm{mg} / \mathrm{L})$ than in LTA-treated quarters $(77 \pm 18$ $\mathrm{mg} / \mathrm{L})$. In conclusion, a mammary inflammation on a quantitatively similar level based on SCC increase achieves a more efficient transfer of blood components such as $\mathrm{IgG}_{2}$ via the blood-milk barrier if induced by LPS from E. coli than by LTA from Staph. aureus. This pathogen-specific difference may play an important role in the cure rate of the respective intramammary infection, which is usually lower in Staph. aureus- than in E. coli-induced mastitis.

Key words: mastitis, blood-milk barrier, lipoteichoic acid, lipopolysaccharide

Received September 26, 2012.

Accepted November 2, 2012.

${ }^{1}$ Corresponding author: olga.wellnitz@vetsuisse.unibe.ch

\section{Short Communication}

Intramammary infection with Escherichia coli usually causes acute clinical mastitis (Hogan and Smith, 2003), indicating a powerful combat of the immune system against the pathogen. In contrast, intramammary Staphylococcus aureus infections are often characterized by chronic and subclinical diseases (Sutra and Poutrel, 1994), and the pathogen seems to be able to prevent significant activity of the immune system. Lipoteichoic acid (LTA) and LPS are cell wall components of Staph. aureus and E. coli, respectively, which are generally accepted as major bacterial components that induce the mammary immune defense. These cell wall components are experimentally used to investigate the mammary immune response (Schmitz et al., 2004; Werner-Misof et al., 2007; Rainard et al., 2008). Choosing dosages to standardize the immune response quantitatively based on a similar SCC increase allowed the study of qualitative differences between these pathogenic components (Wellnitz et al., 2011). Differences in the induction of the mammary immune response by intramammary challenge with LPS and LTA were shown by a different induction of expression of different immune factors (Wellnitz et al., 2011), which most likely plays a role in the development of different mastitis severities.

During inflammation of the mammary gland, a massive leakage of blood constituents into milk occurs due to blood-milk barrier alteration (Burton and Erskine, 2003). Besides SCC, the concentrations of several other parameters increase in milk in response to inflammation of the mammary gland. Not all of these parameters may contribute to the immune response. Immunoglobulin $\mathrm{G}$ is the major immunoglobulin in ruminant milk (Butler, 1983). The subclass $\operatorname{IgG}_{1}$ is the predominant antibody type in milk from healthy quarters because of an active, selective $\operatorname{IgG}_{1}$ transport across the bloodmilk barrier via the neonatal $\mathrm{Fc}$ receptor $(\mathrm{FcRn})$ system (Baker et al., 2009). In mastitic milk, IgG $\mathrm{G}_{2}$ becomes the predominant antibody (Caffin and Poutrel, 1988). It is considered to be the main opsonin supporting neutrophil phagocytosis in the bovine mammary gland and, therefore, plays an important role in the combat against mastitis pathogens (Burton and Erskine, 2003). 
L-Lactate (hereafter referred to as lactate) is another blood component that increases in milk during mastitis and is proposed to be used as an early indicator to detect mastitis (Davis et al., 2004). Leukocytes as a source of lactate in milk during an immune response have been considered (Davis et al., 2004). Recently, we described the blood as a major source of milk lactate that leaks into milk as a result of the impairment of the blood-milk barrier during the immune response (Lehmann et al., 2013). The aim of the current study was to investigate the transfer of immunoglobulins and lactate from blood into milk due to a change in the blood-milk barrier integrity after an intramammary challenge with LPS from E. coli and LTA from Staph. aureus with a comparable SCC increase in milk.

In 13 dairy cows, a similar SCC increase (maximum $\log \mathrm{SCC} / \mathrm{mL}: 7)$ was achieved by intramammary challenge of 1 quarter with $20 \mu \mathrm{g}$ of LTA $(\mathrm{n}=5)$ from a Staph. aureus strain that induced a chronic bovine mastitis, or with $0.2 \mu \mathrm{g}$ of LPS $(\mathrm{n}=8)$ from $E$. coli that induced acute bovine mastitis, as previously described (Figure 1; Wellnitz et al., 2011). In plasma (jugular vein) and milk samples $(\sim 10 \mathrm{~mL})$ taken hourly from challenged and control quarters, $\operatorname{IgG}_{1}$ and $\mathrm{IgG}_{2}$ concentrations were analyzed using ELISA (bovine $\operatorname{IgG}_{1} / \operatorname{IgG}_{2}$ ELISA Quantitation Set; Bethyl Laboratories Inc., LuBioScience GmbH, Lucerne, Switzerland). The procedure was performed according to the manufacturer's protocol. A blocking reagent consisting of fish gelatin [1 mL of fish skin gelatin (G7765; Sigma-Aldrich, Steinheim, Germany) in $20 \mathrm{~mL}$ of bidistilled water] was used to avoid matrix effects. Coefficients of variation, calculated using a control sample on each plate, were 10 and $20 \%$ within and between assays, respectively. Lactate concentrations were measured using the test kit Lactate PAP (bioMérieux, Marcy l'Étoile, France) with an automated analyzer (Cobas Mira; Roche Diagnostics International AG, Rotkreuz, Switzerland) according to the manufacturer's instructions.

Data are presented as means \pm standard error of the mean. Lactate concentrations are presented and statistically evaluated on a logarithmic scale $\left(\log _{10}\right)$ to ensure normal distribution. Differences within treatment group to time point 0 and between-LPS and -LTA treatments within each time point (hourly) were tested for significance $(P<0.05)$ by ANOVA using PROC MIXED SAS (1999-2001, release 8.02; SAS Institute Inc., Cary, NC). The model included time, treatment, and their interaction as fixed effects, and quarter within cow as repeated subject. A Tukey-Kramer adjustment was used to compensate for multiple comparisons. The significant $(P<$ 0.001) Pearson correlation coefficient (SigmaPlot v11; Systat Software Inc., Chicago, IL) between SCC and $\mathrm{IgG}_{1}$ and $\operatorname{Ig}_{2}$ in LPS-challenged quarters was 0.42 and
0.33 , respectively, and 0.45 and 0.68 between SCC and $\mathrm{IgG}_{1}$ and $\mathrm{IgG}_{2}$ in LTA-challenged quarters, respectively.

In blood $\operatorname{IgG}_{1}$ and $\operatorname{IgG}_{2}$, concentrations were $16.5 \pm$ $1.1 \mathrm{mg} / \mathrm{mL}$ and $35.4 \pm 6.8 \mathrm{mg} / \mathrm{mL}$, respectively, and did not change throughout the experiment. Although IgG concentrations in serum are known to be variable due to different factors such as age and lactational stage (Mallard et al., 1983), these are relatively high values compared with those in other studies where concentrations around $10 \mathrm{mg} / \mathrm{mL}$ were found for both immunoglobulins (Butler, 1983; Caffin and Poutrel, 1988). Reasons for that remain unclear. The test kits were validated according the manufacturer recommendations. Milk $\operatorname{IgG}_{1}$ concentrations (Figure $2 \mathrm{~A}$ ) were 68 $\pm 6,63 \pm 5$, and $83 \pm 12 \mu \mathrm{g} / \mathrm{mL}$ in control, LPS-, and LTA-challenged quarters before $(0 \mathrm{~h})$ challenge, respectively. In LPS-challenged quarters, IgG $_{1}$ concentrations increased at 4 and $5 \mathrm{~h}$ and from $7 \mathrm{~h}$ after challenge until the end of the experiment. The maximum of $105 \pm 13$ $\mu \mathrm{g} / \mathrm{mL}$ was reached $5 \mathrm{~h}$ after challenge. In control and LTA-challenged quarters, milk $\operatorname{IgG}_{1}$ concentrations did not significantly increase.

Milk $\mathrm{IgG}_{2}$ concentrations (Figure $2 \mathrm{~B}$ ) were $30 \pm 6$, $32 \pm 8$, and $23 \pm 8 \mu \mathrm{g} / \mathrm{mL}$, in control, LPS-, and LTAchallenged quarters before $(0 \mathrm{~h})$ challenge, respectively. Milk $\mathrm{IgG}_{2}$ concentrations increased at $3 \mathrm{~h}$ in LPSchallenged quarters, reached the maximum of $173 \pm 58$ $\mu \mathrm{g} / \mathrm{mL}$ at $6 \mathrm{~h}$ after challenge, and stayed elevated until the end of the experiment. In LTA-challenged quarters, $\mathrm{IgG}_{2}$ was increased at $6 \mathrm{~h}$, reached a maximum of 67 $\pm 9 \mu \mathrm{g} / \mathrm{mL}$ at $8 \mathrm{~h}$, and stayed elevated until $11 \mathrm{~h}$ after

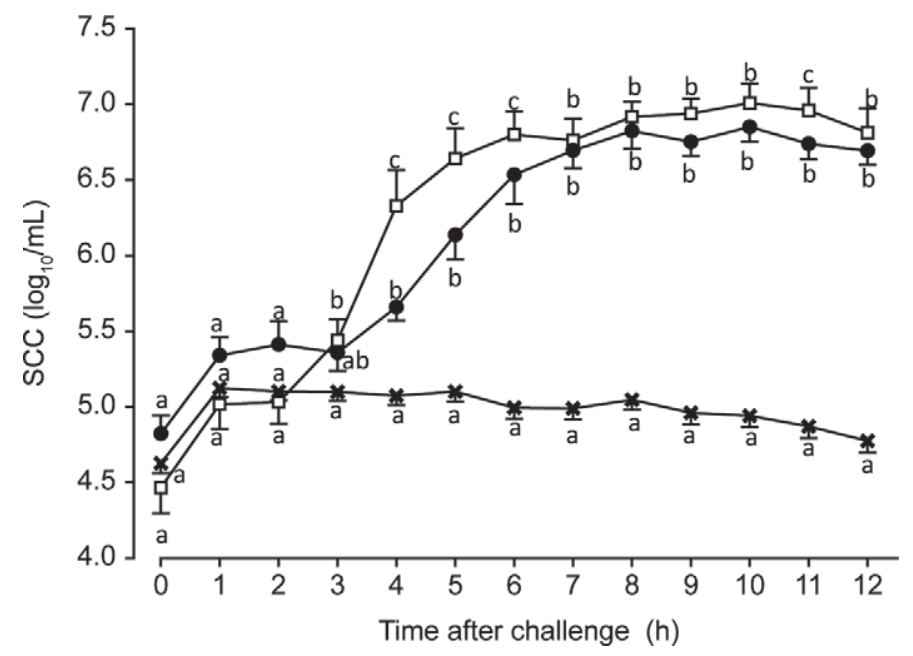

Figure 1. Milk SCC in LPS-challenged quarters $(\square ; \mathrm{n}=8)$, in lipoteichoic acid (LTA)-challenged quarters $(\mathbf{\bullet} ;=5)$, and in control quarters $(\mathrm{x} ; \mathrm{n}=13)$. Means without common letters $(\mathrm{a}-\mathrm{c})$ are significantly different between groups within a time point $(P<0.05)$. Data are presented as means \pm SEM. Reproduced with permission from Wellnitz et al. (2011). 

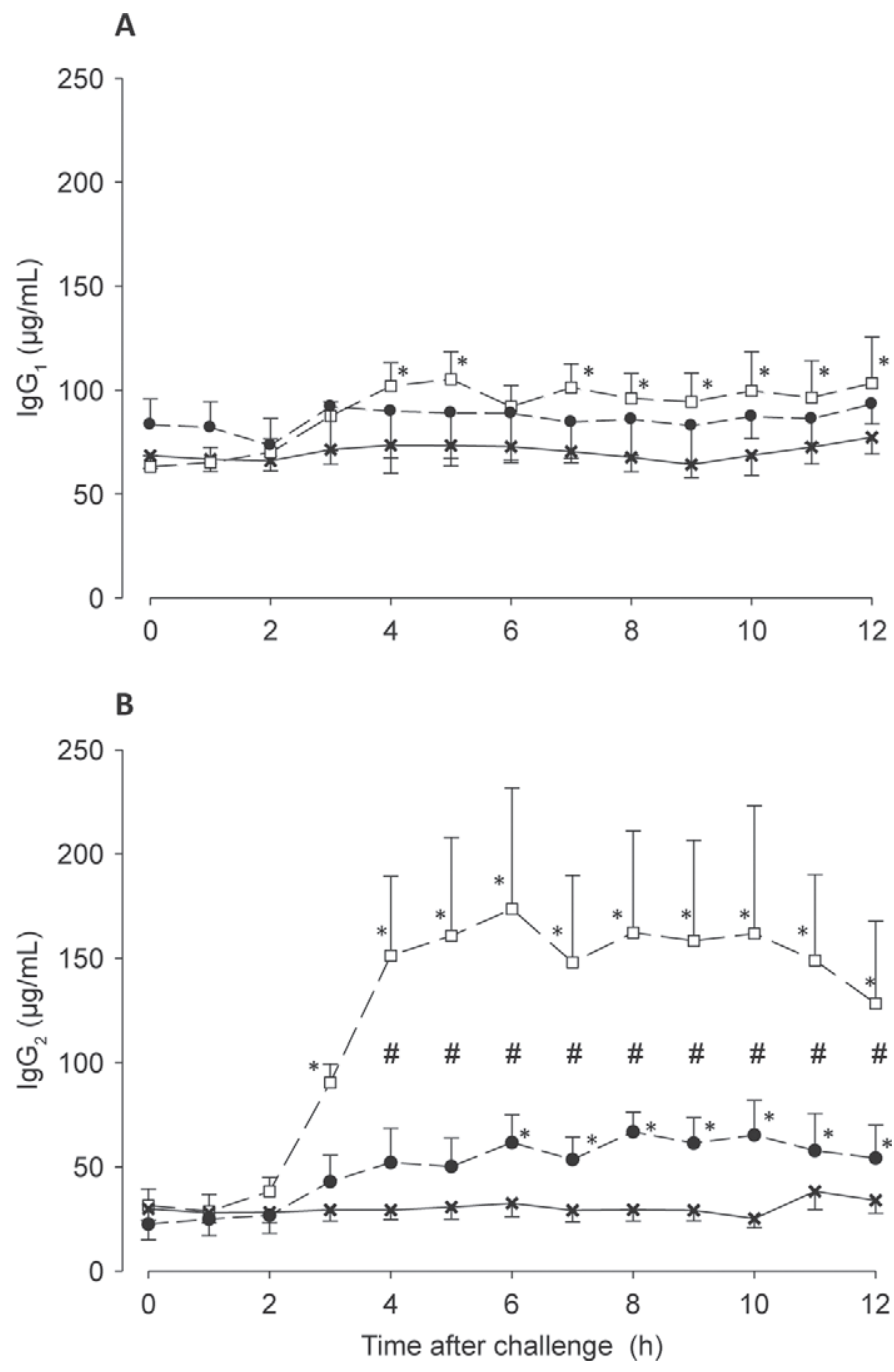

Figure 2. Milk $\operatorname{IgG}_{1}(\mathrm{~A})$ and $\operatorname{IgG}_{2}$ (B) concentrations in LPSchallenged quarters $(\square ; \mathrm{n}=8)$, in lipoteichoic acid (LTA)-challenged quarters $(\bullet ; \mathrm{n}=5)$, and in control quarters $(\mathrm{x} ; \mathrm{n}=13) .{ }^{*}$ indicates the first and subsequent time points with a significant $(P<0.05)$ difference compared with time 0 ; \# indicates significant $(P<0.05)$ differences between LPS- and LTA-challenged quarters within a time point. Data are presented as means \pm SEM.

challenge. In control quarters, milk $\operatorname{Ig}_{2}$ concentrations did not significantly increase.

The present study clearly shows that LPS of E. coli obviously opens the blood-milk barrier to a greater extent than LTA from Staph. aureus, despite a similar SCC increase in response to both treatments. This mechanism could be involved in the mainly chronic development of mastitis by Staph. aureus because an insufficient amount of antibodies and other immune factors from blood are transferred into milk due to a reduced opening of the blood-milk barrier induced by these bacteria.
Concentrations of $\operatorname{IgG}_{2}$ in milk raised to a greater extent ( 5 fold after LPS challenge) than $\operatorname{IgG}_{1}$ (3 fold after LPS challenge) although these molecules have comparable molecular weights of approximately $160 \mathrm{kDa}$ (Butler, 1983) and should be able to pass the bloodmilk barrier in a comparable way. The $\mathrm{IgG}_{1}: \mathrm{IgG}_{2}$ ratio in milk at $5 \mathrm{~h}$ after LPS challenge was 1:1.5, whereas the ratio in blood was 1:2.1. This was mainly due to the specific transport of $\operatorname{IgG}_{1}$ (Mayer et al., 2005) that was also responsible for a 2.5:1 ratio in milk before LPS challenge. In addition, specific transport of $\operatorname{IgG}_{2}$ has been discussed (Newby and Bourne, 1977) and binding of $\mathrm{IgG}_{2}$ to mammary epithelial cells has been reported (Sasaki et al., 1977). However, during lactation of the healthy mammary gland, passive transfer of $\mathrm{IgG}_{2}$ from the blood is assumed (Guidry et al., 1980).

As $\mathrm{IgG}_{2}$ plays a particular role in the mammary immune defense, the availability of antibodies in the milk can be crucial for mastitis defense, specifically if antibodies against the invading mastitis pathogens are available in the blood. Although $\operatorname{IgG}_{2}$ also enter the milk bound to PMNL (Butler, 1983), the majority of milk $\mathrm{IgG}_{2}$ that appear in milk during mammary inflammation leak into mammary gland from the blood (Burton and Erskine, 2003). That differences in the $\mathrm{IgG}_{2}$ content in the milk during mastitis can depend on the pathogen has been reported (Caffin and Poutrel, 1988).

Lactate is another blood component whose appearance in milk was tested with the intramammary LPS or LTA challenge. The blood lactate concentration was $54.9 \pm 1.2 \mathrm{mg} / \mathrm{L}$ before LPS challenge and did not change throughout the experiment. Lactate concentrations in milk (Figure 3) were increased at $4 \mathrm{~h}$ after challenge in LPS-treated quarters and $5 \mathrm{~h}$ after challenge in LTA-treated quarters and both stayed elevated until the end of the experiment. At $4 \mathrm{~h}$ after challenge to $11 \mathrm{~h}$ after challenge, the lactate concentrations in milk were higher in LPS- than in LTA-treated quarters. This greater increase in lactate concentration in milk of quarters challenged with LPS compared with quarters challenged with LTA also shows a different characteristic in the change of blood-milk barrier permeability in response to E. coli compared with Staph. aureus endotoxin. The small molecular size (90 Da) of lactate facilitates transfer from blood into milk. However, milk concentration of lactate increased up to 4.0-fold higher levels of those in blood $(220.7 \pm 48.1 \mathrm{mg} / \mathrm{L})$ at $8 \mathrm{~h}$ after LPS challenge and to 1.4 fold $(76.8 \pm 18.3 \mathrm{mg} / \mathrm{L})$ $10 \mathrm{~h}$ after LTA challenge. This effect was seen before (Lehmann et al., 2013). This effect was suggested to be due to additional lactate production and release during anaerobic metabolism by milk and epithelial cells in the gland (Silanikove et al., 2011) or to be an effect of an 


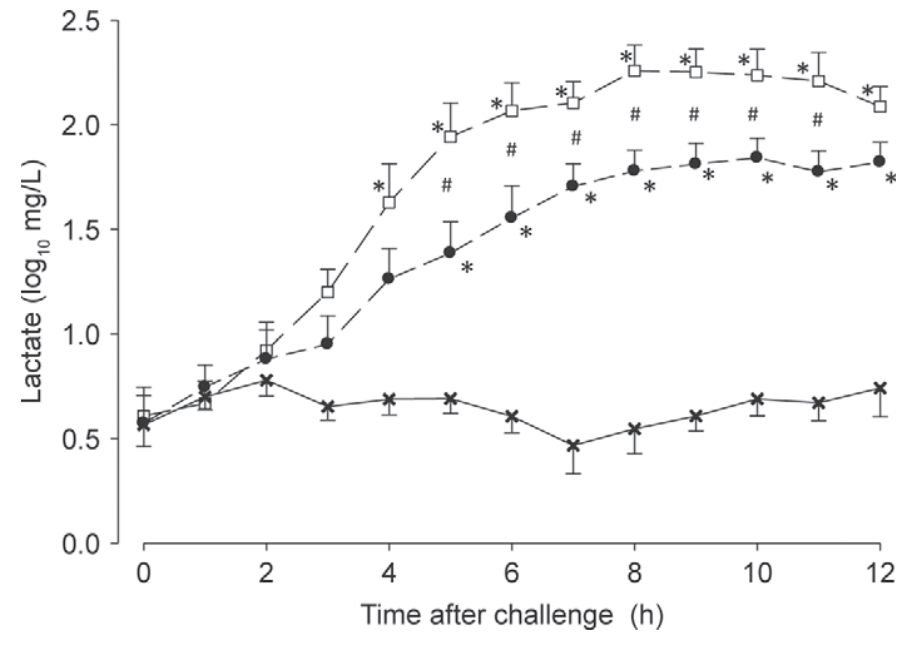

Figure 3. Milk lactate concentrations in LPS-challenged quarters $(\square ; \mathrm{n}=8)$, in lipoteichoic acid (LTA)-challenged quarters $(\mathbf{0} ; \mathrm{n}=$ $5)$, and in control quarters $(\mathrm{x} ; \mathrm{n}=13) .{ }^{*}$ indicates the first and subsequent time point with a significant $(P<0.05)$ difference compared with time 0 ; \# indicates significant $(P<0.05)$ differences between LPS- and LTA-challenged quarters within a time point. Data are presented as means \pm SEM.

additional transporter system for lactate, which could be via aquaporins, as aquaporins transport lactate (Conde et al., 2010) and aquaporins are present in the bovine mammary gland (Mobasheri et al., 2011).

Mammary challenge equalized for SCC increases produces a greater and differential permeability of the blood-milk barrier for immunoglobulins when induced by LPS from E. coli compared with LTA from Staph. aureus. Thus, more efficient transfer of blood components such as $\mathrm{IgG}_{2}$ is achieved with $E$. coli, which predominantly induces acute and severe mastitis compared with LTA from Staph. aureus, which is responsible for more chronic and subclinical mastitis. This effect could have an important influence on the cure rate of the respective IMI, which is usually lower in Staph. aureusthan in E. coli-induced mastitis, specifically if antibodies against the mastitis pathogen are present in the blood (e.g., after vaccination).

\section{ACKNOWLEDGMENTS}

The laboratory work during IgG analyses by Claudine Morel (Veterinary Physiology, Vetsuisse Faculty, University of Bern, Switzerland) is gratefully acknowledged. This study was partially funded by a grant (FOR 585) from the Deutsche Forschungsgemeinschaft, Bonn, Germany.

\section{REFERENCES}

Baker, K., S.-W. Qiao, T. Kuo, K. Kobayashi, M. Yoshida, W. I. Lencer, and R. S. Blumberg. 2009. Immune and non-immune functions of the (not so) neonatal Fc receptor, FcRn. Semin. Immunopathol. 31:223-236.

Burton, J. L., and R. J. Erskine. 2003. Immunity and mastitis. Some new ideas for an old disease. Vet. Clin. North Am. Food Anim. Pract. 19:1-45.

Butler, J. E. 1983. Bovine immunoglobulins: An augmented review. Vet. Immunol. Immunopathol. 4:43-152.

Caffin, J. P., and B. Poutrel. 1988. Physiological and pathological factors influencing bovine immunoglobulin $\mathrm{G}_{2}$ concentration in milk. J. Dairy Sci. 71:2035-2043.

Conde, A., G. Diallinas, F. Chaumont, M. Chaves, and H. Gerós. 2010. Transporters, channels, or simple diffusion? Dogmas, atypical roles and complexity in transport systems. Int. J. Biochem. Cell Biol. $42: 857-868$

Davis, S. R., V. C. Farr, C. G. Prosser, G. D. Nicholas, S. Turner, J. Lee, and A. L. Hart. 2004. Milk L-lactate concentration is increased during mastitis. J. Dairy Res. 71:175-181.

Guidry, A. J., J. E. Butler, R. E. Pearson, and B. T. Weinland. 1980 $\operatorname{IgA}, \operatorname{IgG}_{1}, \operatorname{IgG}_{2}, \operatorname{IgM}$, and BSA in serum and mammary secretion throughout lactation. Vet. Immunol. Immunopathol. 1:329-341.

Hogan, J., and K. L. Smith. 2003. Coliform mastitis. Vet. Res. $34: 507-519$

Lehmann, M., O. Wellnitz, and R. M. Bruckmaier. 2013. Concomitant lipopolysaccharide-induced transfer of blood-derived components including immunoglobulins into milk. J. Dairy Sci. 96:889-896. http://dx.doi.org/10.3168/jds.2012-5410.

Mallard, B. A., E. B. Burnside, J. H. Burton, and B. N. Wilkie. 1983. Variation in serum immunoglobulins in Canadian Holstein-Friesians. J. Dairy Sci. 66:862-866.

Mayer, B., M. Doleschall, B. Bender, J. Bartyik, Z. Bosze, L. V. Frenyó, and I. Kacskovics. 2005. Expression of the neonatal Fc receptor $(\mathrm{FcRn})$ in the bovine mammary gland. J. Dairy Res. 72(Special Issue):107-112.

Mobasheri, A., B. H. Kendall, J. E. Maxwell, A. V. Sawran, A. J. German, D. Marples, M. R. Luck, and M. D. Royal. 2011. Cellular localization of aquaporins along the secretory pathway of the lactating bovine mammary gland: An immunohistochemical study. Acta Histochem. 113:137-149.

Newby, T. J., and J. Bourne. 1977. The nature of the local immune system of the bovine mammary gland. J. Immunol. 118:461-465.

Rainard, P., A. Fromageau, P. Cunha, and F. B. Gilbert. 2008. Staphylococcus aureus lipoteichoic acid triggers inflammation in the lactating bovine mammary gland. Vet. Res. 39:52

Sasaki, M., B. L. Larson, and D. R. Nelson. 1977. Kinetic analysis of the binding of immunoglobulins $\mathrm{IgG}_{1}$ and $\mathrm{IgG}_{2}$ to bovine mammary cells. Biochim. Biophys. Acta 497:160-170.

Schmitz, S., M. W. Pfaffl, H. H. Meyer, and R. M. Bruckmaier. 2004 Short-term changes of mRNA expression of various inflammatory factors and milk proteins in mammary tissue during LPS-induced mastitis. Domest. Anim. Endocrinol. 26:111-126.

Silanikove, N., A. Rauch-Cohen, F. Shapiro, S. Blum, A. Arieli, and G. Leitner. 2011. Lipopolysaccharide challenge of the mammary gland in bovine induced a transient glandular shift to anaerobic metabolism. J. Dairy Sci. 94:4468-4475.

Sutra, L., and B. Poutrel. 1994. Virulence factors involved in the pathogenesis of bovine intramammary infections due to Staphylococcus aureus. J. Med. Microbiol. 40:79-89.

Wellnitz, O., E. T. Arnold, and R. M. Bruckmaier. 2011. Lipopolysaccharide and lipoteichoic acid induce different immune responses in the bovine mammary gland. J. Dairy Sci. 94:5405-5412.

Werner-Misof, C., M. W. Pfaffl, and R. M. Bruckmaier. 2007. Dosedependent immune response in milk cells and mammary tissue after intramammary administration of lipopolysaccharide in dairy cows. Vet. Med. Czech 52:231-244. 